\title{
Role of fibronectin-binding protein A in Clostridium difficile intestinal colonization
}

Correspondence

Imad Kansau

imad.kansau@u-psud.fr

Received 24 December 2010

Accepted 21 February 2011

\author{
Amira Barketi-Klai, Sandra Hoys, Sylvie Lambert-Bordes, Anne Collignon \\ and Imad Kansau
}

EA 4043, USC INRA 'Ecosystème microbien digestif et santé', Faculté de Pharmacie, Université Paris-Sud 11, Châtenay-Malabry, France

Clostridium difficile is a frequent cause of severe, recurrent, post-antibiotic diarrhoea and pseudomembranous colitis. Its pathogenicity is mediated mainly by two toxins, TcdA and TcdB. However, different adhesins have also been described as important colonization factors which are implicated in the first step of the intestinal infection. In this study, we focused our interest on one of these adhesins, fibronectin-binding protein $A(F b p A)$, and on its role in the intestinal colonization process. A mutant of $\mathrm{FbpA}(\mathrm{CD} \Delta \mathrm{FbpA})$ was constructed in C. difficile strain $630 \Delta$ erm by using ClosTron technology. This mutant was characterized in vitro and in vivo and compared to the isogenic wild-type strain. Adhesion of the CD $\Delta \mathrm{FbpA}$ mutant to the human colonic epithelial cell line Caco-2 and to mucus-secreting HT29-MTX cells was examined. Surprisingly, the CD $\triangle \mathrm{FbpA}$ mutant adhered more than the wild-type parental strain. The $\mathrm{CD} \Delta \mathrm{FbpA}$ mutant was also analysed in three different mouse models by following the intestinal implantation kinetics (faecal shedding) and caecal colonization (7 days post-challenge). We showed that in monoxenic mice, CD $\Delta \mathrm{FbpA}$ shed $\mathrm{C}$. difficile in faeces at the same rate as that of the isogenic wild-type strain but its colonization of the caecal wall was significantly reduced. In dixenic mice, the shedding rate was slower for the CD $\Delta$ FbpA mutant than for the isogenic wildtype strain during the first days of infection, but no significant difference was observed in caecal colonization. Similar rates of intestinal implantation and caecal colonization were observed for both strains in assays performed in human microbiota-associated mice. Taken together, our data suggest that FbpA plays a role in intestinal colonization by C. difficile.

\section{INTRODUCTION}

Clostridium difficile is an emerging nosocomial pathogen of increasing importance and virulence, especially with the appearance of hypervirulent strains in the last few years. It is the major cause of pseudomembranous colitis and causes $15-20 \%$ of antibiotic-associated diarrhoea cases associated with the use of antibiotic treatment (Cartman et al., 2010; Poxton et al., 2001). Antibiotics disrupt the normal intestinal microbiota, allowing $C$. difficile to colonize the gut. The pathogenesis of $C$. difficile infections has been attributed to two toxins, TcdA and TcdB, which act as glycosyltransferases and modify small GTPases of the Rho protein family within the host cell, resulting in alterations in the cytoskeleton (Genth et al., 2008; Voth \& Ballard, 2005). Apart from these two toxins, a binary toxin is also produced by a few strains but little is known about the other virulence factors which are involved in the colonization process. Presently, only a few cell surface proteins have been identified and characterized. These proteins include the S-layer proteins (Calabi et al., 2002; Cerquetti et al., 2000), the flagellum and its components (Tasteyre et al., 2001), the cell wall protein Cwp66 (Waligora et al., 2001), the protease Cwp84 (Janoir et al., 2007) and the heat-shock protein GroEL (Hennequin et al., 2001). This study focuses on one of the adhesive proteins, the fibronectin-binding protein (annotated FbpA in the 630 strain and Fbp68 in the 79-685 strain) (Hennequin et al., 2001).

Fibronectin is a dimeric glycoprotein $(\sim 440 \mathrm{kDa})$ which is present in a soluble form in plasma and in an immobilized form on cell surfaces and in extracellular matrix (Joh et al., 1999). It is an important target for bacterial attachment in many pathogens, such as Streptococcus pyogenes, Streptococcus pneumoniae and Listeria monocytogenes, where fibronectin-binding proteins are important virulence factors (Courtney et al., 1999; Dramsi et al., 2004; Holmes et al., 2001; Molinari et al., 1997; Terao et al., 2001). In a previous study, a fibronectin-binding protein, Fbp68 from C. difficile strain 79-685, was identified as one of its several adhesins. It was reported that Fbp68 is able to adhere to soluble and to immobilized fibronectin, as well as to fibrinogen. Competitive adherence inhibition assays have shown that antibodies raised against Fbp68 partially inhibit the attachment of $C$. difficile to fibronectin and Vero cells (Hennequin et al., 2003). 
Thanks to the new ClosTron gene knockout system which has been successfully developed by Heap et al. (2007), we constructed a mutant in the $f b p A$ gene. The mutant was characterized in vitro and in vivo and compared to the isogenic wild-type strain in order to further understand the role of fibronectin-binding protein FbpA in the pathogenesis of C. difficile.

\section{METHODS}

Bacterial strains and growth conditions. The C. difficile $630 \Delta \mathrm{erm}$ strain and the $\mathrm{CD} \Delta \mathrm{FbpA}$ mutants generated in $630 \Delta \mathrm{erm}$ were grown in brain-heart infusion (BHI) broth and in Columbia cysteine agar supplemented with $0.4 \%$ C. difficile selective supplements (Oxoid) and $4 \%$ horse blood (CC) at $37{ }^{\circ} \mathrm{C}$ under anaerobic conditions. Escherichia coli TOP10 (Invitrogen) was used for gene cloning and $E$. coli HB101 RP4 was used for conjugation. Both strains were grown in Luria-Bertani medium under agitation at $37{ }^{\circ} \mathrm{C}$. Kanamycin and ampicillin were used for E. coli at 25 and $100 \mu \mathrm{g} \mathrm{ml}^{-1}$, respectively.

Construction of the $\mathbf{C}$. difficile $\triangle$ FbpA mutant. The ClosTron gene insertional knockout system was used for the construction of the CD $\Delta$ FbpA mutant (Heap et al., 2007). Different insertion sites within the $f b p A$ gene were identified using the Targetron Design Site program (http://www.sigma-genosys.com/targetron). Two different antisense sites were chosen $(640 \mathrm{bp}$ and $1370 \mathrm{bp}$ from the start codon). A $350 \mathrm{bp}$ fragment was generated by SOEing PCR with primers designed by inputting the targeted sequence into the webbased program (Table 1). The PCR product was excised and purified from a $1 \%$ agarose gel. It was then cloned into pMTL007 via HindIII and BsrGI and transformed into E. coli TOP10. Sequence confirmation of purified plasmid constructs was performed using specific pMTL007 primers (Table 1). The derivative pMTL007 plasmid construct was transformed by electroporation into the conjugative donor E. coli $\mathrm{HB} 101 \mathrm{RP} 4$ and transferred by conjugation into $C$. difficile $630 \Delta \mathrm{erm}$. Successful transconjugants were selected onto CC medium supplemented with $15 \mu \mathrm{g}$ thiamphenicol $\mathrm{ml}^{-1}$. The thiamphenicol-resistant colonies were then restreaked onto CC medium supplemented with $5 \mu \mathrm{g}$ erythromycin $\mathrm{ml}^{-1}$ to select for the presence of spliced ErmRAM, which indicates intron integration. The obtained integrants were screened by colony PCR using primers specific for $f b p A$ and the inserted RAM (retrotransposition-activated marker) (Table 1). Sequencing of these PCR products allowed us to confirm the insertion in the targeted gene.

Western blot analysis. C. difficile was grown overnight in BHI broth and washed twice with PBS. The pellet was resuspended in Tris/ $\mathrm{HCl}$ (62 mmol l${ }^{-1}$; $\mathrm{pH} 6.8$ ) supplemented with $60 \mu \mathrm{g}$ mutanolysin $\mathrm{ml}^{-1}$ and incubated at $37^{\circ} \mathrm{C}$ for $1 \mathrm{~h} 30 \mathrm{~min}$. The suspension was then mixed for $5 \mathrm{~min}$. Protein extracts were separated by $10 \%$ SDS-PAGE and electrotransferred to Hybond-P membranes (GE Healthcare). After blocking with BSA, the blot was incubated with a 1/10000 dilution of an anti-FbpA polyclonal antibody (Hennequin et al., 2003), followed by incubation with an anti-rabbit IgG alkaline phosphatase conjugate (Sigma; 1/20000). The blot was then washed and reacted with the substrate solution BCIP/NBT (Sigma).

Immobilized fibronectin-binding assay. Binding of C. difficile to immobilized human fibronectin (Sigma) on microtitre plates (Nunc) was measured as described previously (Hennequin et al., 2003). In brief, wells were coated overnight at $4{ }^{\circ} \mathrm{C}$ and for $1 \mathrm{~h}$ at $37^{\circ} \mathrm{C}$ with $10 \mu \mathrm{g}$ fibronectin $\mathrm{ml}^{-1}$. After blocking with $1 \%$ BSA in PBS for $2 \mathrm{~h}$, the plates were incubated for $30 \mathrm{~min}$ with $100 \mu \mathrm{l}$ of various concentrations of a late stationary phase $C$. difficile culture. After washing five times with PBS, the bound bacteria were detected using an anti-C. difficile polyclonal antibody diluted to $1 / 2500$. Antibodies were then detected by alkaline phosphatase-conjugated anti-rabbit IgG (Sigma; 1/2500) and by $p$-nitrophenyl phosphate substrate (Sigma). The resulting colour development was measured at $A_{595}$.

Adhesion to Caco-2 and HT29 cell lines. In vitro adhesion of $C$. difficile was studied on human colonic enterocyte-like Caco-2 cells (passage 71) and on mucus-secreting HT29-MTX cells (passage 45) in culture. Epithelial cells were cultured in 24-well plates in Dulbecco modified Eagle's medium (DMEM; Gibco) supplemented with $10 \%$ $(\mathrm{v} / \mathrm{v})$ fetal bovine serum and $1 \%(\mathrm{v} / \mathrm{v})$ non-essential amino acids (only for Caco-2 cells) and incubated at $37{ }^{\circ} \mathrm{C}$ in a $5 \% \mathrm{CO}_{2}$ incubator. The culture medium was changed daily. Differentiated monolayers were used 15 days (Caco-2) and 21 days (HT29-MTX) after seeding. Overnight cultures of $C$. difficile were pelleted, washed and resuspended in DMEM without fetal bovine serum and without non-essential amino acids. After counting in a Salumbini chamber, the bacterial culture was adjusted to $10^{8}$ bacteria $\mathrm{ml}^{-1}$. The real density of the inoculum was determined subsequently from viable c.f.u. counts. Bacterial suspension $(0.5 \mathrm{ml})$ was added to each well and plates were then incubated for $1 \mathrm{~h} 30 \mathrm{~min}$ at $37^{\circ} \mathrm{C}$ under

Table 1. Primers used in this study for mutant generation

\begin{tabular}{|c|c|}
\hline Primer & Sequence $\left(5^{\prime} \rightarrow 3^{\prime}\right)$ \\
\hline $\mathrm{IBS}_{640}$ & AAAAAAGCTTATAATTATCCTTACTGCTCTGTAGCGTGCGCCCAGATAGGGTG \\
\hline EBS1d $_{640}$ & CAGATTGTACAAATGTGGTGATAACAGATAAGTCTGTAGCAATAACTTACCTTTCGT \\
\hline $\mathrm{EBS}_{640}$ & TGAACGCAAGTTTCTAATTTCGGTTAGCAGTCGATAGAGGAAAGTGTCT \\
\hline $\mathrm{IBS}_{1370}$ & AAAAAAGCTTATAATTATCCTTAGTATCCTTTTTAGTGCGCCCAGATAGGGTG \\
\hline EBS1d $_{1370}$ & CAGATTGTACAAATGTGGTGATAACAGATAAGTCTTTTTACTTAACTTACCTTTCTGT \\
\hline EBS2 1370 & TGAACGCAAGTTTCTAATTTCGATTGATACTCGATAGAGGAAAGTGTCT \\
\hline EBSu & CGAAATTAGAAACTTGCGTTCAGTAAAC \\
\hline $\mathrm{FbpA}_{640}-\mathrm{F}$ & TTCATTGCCACCAGAACAAA \\
\hline $\mathrm{FbpA}_{640}-\mathrm{R}$ & AGAAATCTTCCAGAATACGAGACA \\
\hline $\mathrm{FbpA}_{1370}-\mathrm{F}$ & CACCATCTGAAAATGCTCAAAA \\
\hline $\mathrm{FbpA}_{1370}-\mathrm{R}$ & GGGACTTCCTTACCAGCACA \\
\hline ErmRAM-F & ACGCGTTATATTGATAAAAATAATAATAGTGGG \\
\hline ErmRAM-R & ACGCGTGCGACTCATAGCCTTATTTCCTCCCG \\
\hline
\end{tabular}


anaerobic conditions. The non-adherent bacteria were removed by washing five times with PBS and the bound bacteria were detached by adding $0.5 \mathrm{ml} 1 \%$ saponin per well. Serial dilutions were plated on BHI agar plates and c.f.u. were counted after $48 \mathrm{~h}$ of incubation. For each plate, three wells were used to count the number of cultured cells in order to express the results as c.f.u. per cell. Briefly, cells were treated with $200 \mu \mathrm{l}$ trypsin for $10 \mathrm{~min}$ and $300 \mu \mathrm{l}$ DMEM was added. Cells were scraped and homogenized for subsequent enumeration.

The assays were done in triplicate in three independent experiments. Statistical analyses were performed using the Mann-Whitney test with StatEL software. All conclusions were based on $P<0.05$ as significant.

\section{Measurement of bacterial hydrophobicity}

Contact angle measurements. Contact angle measurements were carried out using a G1/G40 (Krüss) goniometer coupled to the Drop Shape Analysis DSAv1.80 software. One hundred and twenty microliters of a bacterial suspension $\left(2 \times 10^{10}\right.$ bacteria $\mathrm{ml}^{-1}$ in $0.15 \mathrm{M}$ PBS) was deposited on a microscope slide and then left to dry for $2 \mathrm{~h}$ at $37^{\circ} \mathrm{C}$. The homogeneity of the bacterial film was checked by differential interference contrast microscopy using a confocal laser scanning microscope (Zeiss LSM 510) with a Plan-Apochromat $\times 63$ / 1.40 oil objective. Drops of ultrapure water were deposited onto the surface and the contact angle was measured immediately after their deposition onto the bacterial film. The values obtained were mean contact angles from three different experiments with three independently grown cultures. For each strain and each experiment, at least eight different drops were measured.

Bacterial adherence to hexadecane. Adherence to hexadecane was tested by the method of Bellon-Fontaine et al. (1996). The washed bacterial pellet was diluted in $0.15 \mathrm{M}$ PBS to a concentration of about $10^{8}$ bacteria $\mathrm{ml}^{-1}$. The $A_{405}$ of this suspension (Ao) was measured using a spectrophotometer (Ultraspec 1000; Amersham Pharmacia Biotech). Each bacterial suspension $(2.4 \mathrm{ml})$ was vortexed for $90 \mathrm{~s}$ with $0.4 \mathrm{ml} n$-hexadecane (Sigma). The mixture was allowed to stand for $15 \mathrm{~min}$ to ensure complete separation of the two phases. The absorbance of the water phase was then measured $(A)$. The percentage bacterial adherence to hexadecane was subsequently calculated by the following equation: \% adherence $=(1-A / A o) \times 100$, where Ao is the $A_{405}$ of the bacterial suspension before mixing and $A$ is the absorbance after mixing. Each experiment was carried out five times with bacteria originating from independent cultures. Statistical analyses were performed using the Mann-Whitney test with StatEL software. All conclusions were based on $P<0.05$ as significant.

In vivo experiments. $\mathrm{C} 3 \mathrm{H} / \mathrm{HeN}$ germ-free and human microbiotaassociated mice from INRA of Jouy-en-Josas (ANAXEM, France) were used. To prepare $C$. difficile for challenge, $C$. difficile was grown in $\mathrm{BHI}$ broth at $37^{\circ} \mathrm{C}$ in an anaerobic chamber overnight. Bacteria were harvested by centrifugation, suspended in PBS and diluted to $2 \times 10^{7}$ cells ml $^{-1}$ after counting with a Salumbini chamber. The real density was determined subsequently from viable c.f.u. counts. Groups of 6-week-old male mice $(n=6)$ were orally challenged with $0.5 \mathrm{ml}$ bacterial suspension and monitored for up to 7 days. Faecal samples were collected every day from each mouse. They were weighed and diluted in PBS in order to obtain a concentration of $10 \mathrm{mg} \mathrm{ml}^{-1}$. The number of bacteria present in faeces was determined by using serial dilutions in PBS and by seeding them on BHI agar. Seven days after $C$. difficile challenge, mice were sacrificed and dissected in order to obtain the entire caecum of each mouse. Each caecum was washed eight times by gentle shaking in PBS buffer, weighed and placed in PBS to a final concentration of $10 \mathrm{mg} \mathrm{ml}^{-1}$. The caecum was then homogenized with an Ultra-Turrax apparatus (IKA-Labortechnik) for $1 \mathrm{~min}$ at 13500 r.p.m. Serial dilutions were seeded and cultured in appropriate media.
Competition experiments were performed by co-infecting the same animal with equal amounts of wild-type and mutant strains. The amount of each bacterium in faeces was obtained by plating on selective plates, according to the erythromycin resistance of the $\mathrm{CD} \Delta \mathrm{FbpA}$ mutant. Experiments on human microbiota-associated mice were performed 2 days after antibiotic treatment. Mice were treated with $3 \mathrm{mg}$ amoxicillin/clavulanic acid (8/1, v/v) (Augmentin; Teva Classics) for 8 days by intragastric gavage. The amount of $C$. difficile in faeces was obtained by plating on $C$. difficile selective plates (CC).

\section{RESULTS AND DISCUSSION}

\section{C. difficile $\triangle$ FbpA mutant does not express FbpA and does not bind fibronectin}

The $C$. difficile $\triangle \mathrm{FbpA}$ mutant was constructed by ClosTron technology. This technique consists of retargeting the mobile group II intron from the ltrB gene of Lactococcus lactis (L1.ltrB), which provides stable insertional inactivation of specific genes and which confers erythromycin resistance via a retrotransposition-activated marker. Two different mutants were obtained in the $f b p A$ gene with two different insertion sites, $640 \mathrm{bp}$ $\left(\mathrm{CD} \Delta \mathrm{FbpA}_{640}\right)$ and $1370 \mathrm{bp}\left(\mathrm{CD} \Delta \mathrm{FbpA}_{1370}\right)$. Disruption of $f b p A$ was confirmed by PCR and by direct sequencing of the junction points. Western blot analysis confirmed that the two mutants did not express FbpA (Fig. 1). It should be noted that FbpA migrates faster (at about $35 \mathrm{kDa}$ ) than expected $(68 \mathrm{kDa})$ in a denaturing gel. It was previously observed that native Fbp68 of the C. difficile 79-685 strain had an aberrant migration on SDS-PAGE (Hennequin et al., 2003). This could be explained either by an unusual conformation of the full-length protein or by another posttranslational processing of the native FbpA in C. difficile. Analysis of the fibronectin-binding properties of the

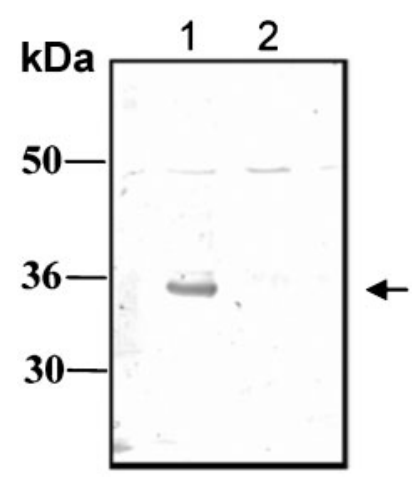

Fig. 1. Lack of FbpA expression by the $\mathrm{CD} \Delta \mathrm{FbpA} \mathrm{A}_{640}$ mutant in Western blot analysis. Whole proteins extracted from cultures $(10 \mathrm{ml})$ of $\mathrm{CD} 630 \Delta$ erm (lane 1) and $\mathrm{CD} \Delta \mathrm{FbpA}_{640}$ (lane 2) were subjected to SDS-PAGE, transferred to Hybond-P membrane and then probed with $1 / 10000$ anti-FbpA polyclonal antibodies. The arrow indicates the location of $\mathrm{FbpA}$, which is present in CD630 $\Delta$ erm but not in $\mathrm{CD} \Delta \mathrm{FbpA}_{640}$. The same result was obtained for CD $\Delta \mathrm{FbpA}_{1370}$. 
mutants compared to those of the wild-type strain showed that both mutants were not able to bind fibronectin immobilized on immunoplates (Fig. 2). These results show that the $f b p A$ gene was really inactivated and that the FbpA protein was no longer expressed in the two mutants. $\mathrm{CD} \triangle \mathrm{FbpA}$ mutants showed the same colony aspect and growth rate as the isogenic wild-type strain (data not shown).

\section{Absence of FbpA affects adhesion of C. difficile to intestinal epithelial cells}

In order to elucidate whether FbpA plays a role in the colonization process, which is the first step in the course of infection, $\mathrm{CD} \Delta \mathrm{FbpA}_{640}$ and $\mathrm{CD} \Delta \mathrm{FbpA}_{1370}$ mutants were analysed for their ability to adhere to cultured intestinal epithelial cells. Only the results obtained with the $\mathrm{CD} \Delta \mathrm{FbpA}_{640}$ mutant are presented. First, we measured adhesion of the CD $\Delta \mathrm{FbpA}$ mutants to Caco-2 cells. Surprisingly, a small but significant increase in adhesion was observed for the mutants $(1.17$ c.f.u. per cell for $\left.\mathrm{CD} \Delta \mathrm{FbpA}_{640}\right)$ as compared to the wild-type strain $\left(5.47 \times 10^{-2}\right.$ c.f.u. per cell $)(P<0.05)$. The $\mathrm{CD} \Delta \mathrm{FbpA}_{640}$ mutant also adhered slightly more (2.6 c.f.u. per cell) than the wild-type strain $\left(3.15 \times 10^{-2}\right.$ c.f.u. per cell) onto HT29MTX cells $(P<0.05)$. The same results were obtained with the two $\mathrm{CD} \triangle \mathrm{FbpA}$ mutants (data not shown for the $\mathrm{CD} \Delta \mathrm{FbpA}_{1370}$ mutant). These striking results suggest that the absence of FbpA leads to some changes in the adhesion properties of $C$. difficile. One hypothesis is that there could be changes in the hydrophobic properties of the bacterial surface. In order to test this hypothesis, we performed measurements of the contact angle between water drops and bacterial films as well as tested adherence to hexadecane for the two $\mathrm{CD} \Delta \mathrm{FbpA}$ mutants and the

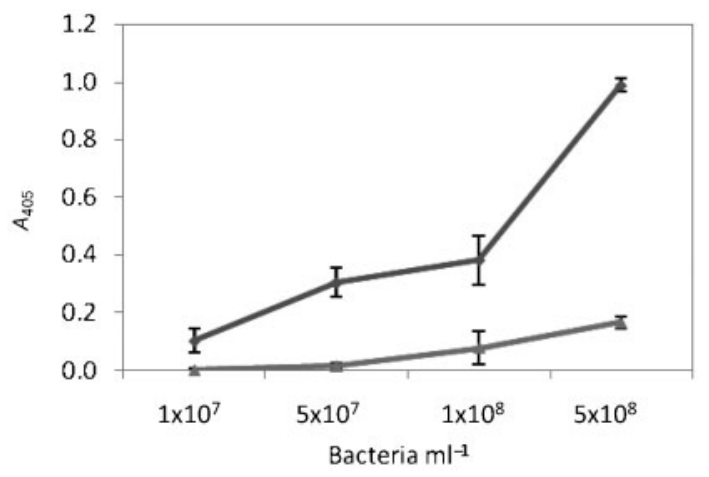

Fig. 2. Binding of the wild-type strain $C D 630 \Delta$ erm $(\diamond)$ and the $\mathrm{CD} \Delta \mathrm{FbpA}_{640}$ mutant $(\boldsymbol{\Delta})$ to immobilized human fibronectin. Various concentrations of $\mathrm{CD} 630 \Delta$ erm or $\mathrm{CD} \Delta \mathrm{FbpA}_{640}$ were added to fibronectin $\left(10 \mu \mathrm{g} \mathrm{ml}^{-1}\right)$-coated wells. Binding was measured by ELISA using an anti-C. difficile polyclonal antibody and an alkaline phosphatase-conjugated anti-rabbit secondary antibody. The $A_{405}$ was measured. The same result was obtained for $\mathrm{CD} \Delta \mathrm{FbpA}_{1370 \text {. }}$ wild-type strain. Using these two techniques we did not observe any significant difference between strain $630 \Delta \mathrm{erm}$, $\mathrm{CD} \Delta \mathrm{FbpA}_{640}$ and $\mathrm{CD} \Delta \mathrm{FbpA}_{1370}$ (Fig. 3a, c; data not shown for the $\mathrm{CD} \Delta \mathrm{FbpA}_{1370}$ mutant). Microscopic analysis (differential interference contrast microscopy) of the bacterial films used for contact angle measurements showed a flat, regular and homogeneous surface for all the tested biofilms (Fig. 3b). These results suggest that hydrophobic properties are not involved in the increased adhesion of $\mathrm{CD} \Delta \mathrm{FbpA}$ mutants to intestinal epithelial cells. The observed increased adherence of these mutants could also be explained by changes in the bacterial surface other than hydrophobicity which lead to an overexposure of other adhesins. Another hypothesis could be changes in the regulation of one or more of the cell wall proteins. Further experiments should be performed in order to confirm these hypotheses. In a previous study, it has already been reported that a $\triangle \mathrm{FbpA}$ mutant in Lactobacillus casei adhered more than the wildtype strain to the HT29-MTX cell line whereas no significant changes were detected in the ability to bind to Caco-2 (Muñoz-Provencio et al., 2010). It was speculated that $L$. casei probably utilizes other FbpA-independent mechanisms for attachment to the HT29 and Caco-2 cell lines or that the contribution of FbpA to binding in these models is small. In another recent report, a $\mathrm{CD} \Delta \mathrm{Fbp} 68$ mutant was constructed in C. difficile 630 (insertion site at $102 \mathrm{bp}$ ) by using the same ClosTron gene knockout system (Lin et al., 2011). The authors assayed adherence to Caco- 2 cells and showed that their mutant had similar fibronectin- and cell-binding activities to the wild-type strain. Contrary to their results, our $\mathrm{CD} \Delta \mathrm{FbpA}$ mutants did not adhere to human fibronectin by comparison with the wild-type CD630 $\Delta$ erm strain. Moreover, adherence of the mutants to cultured cells was tested on two different cell lines, which showed that the $\mathrm{CD} \Delta \mathrm{FbpA}$ mutants adhere slightly more to both Caco-2 cells and mucus-secreting HT29-MTX cells. It is possible that the different genetic background of the mutated bacteria plays a role in the differences observed in the adherence properties.

Still in order to determine the role of FbpA and the implication of its adhesive properties in the colonization of C. difficile, we tested the capacity of the $\mathrm{CD} \Delta \mathrm{FbpA}_{640}$ mutant to colonize the intestine of mice.

\section{FbpA plays a role in intestinal colonization of mice}

In order to assess the capacity of the $\mathrm{CD} \Delta \mathrm{FbpA}_{640}$ mutant to colonize mice, the kinetics of faecal shedding and caecal colonization were studied in three different mouse models. Kinetics of faecal shedding allows measurement of the intestinal implantation of a strain, while caecal colonization allows evaluation of the capacity of one strain to interact with the intestinal epithelium. For each experiment, faeces were collected at specific times during a week and caeca were obtained by sacrificing mice 7 days postchallenge. 
(a)

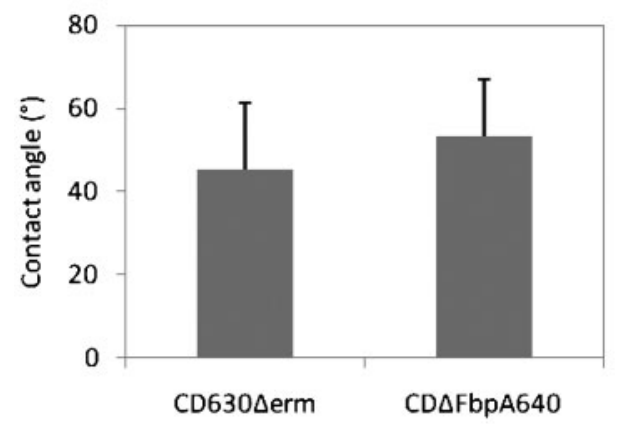

(c)

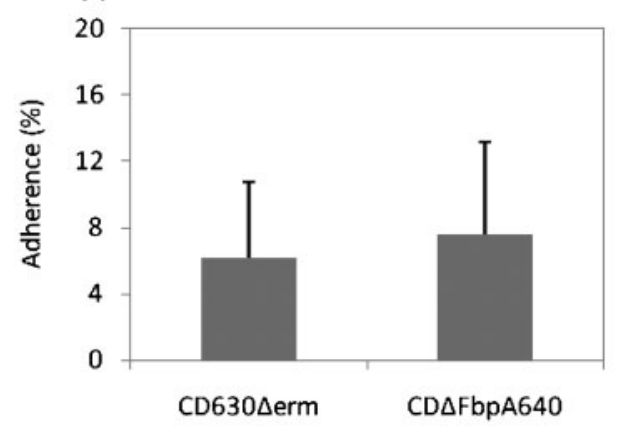

(b)

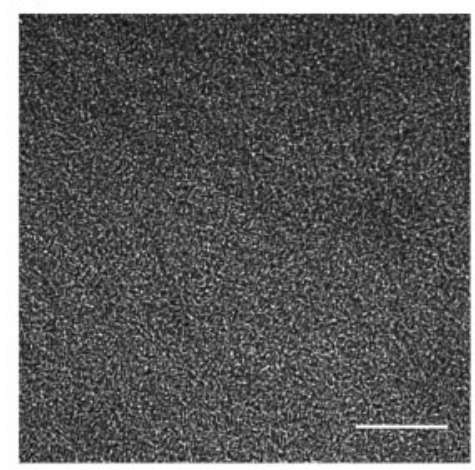

Fig. 3. Hydrophobicity of the wild-type strain CD630 $\Delta$ erm and the CD $\Delta$ FbpA 640 mutant. (a) Contact angle measurements. One hundred and twenty microlitres of a bacterial suspension $\left(2 \times 10^{10}\right.$ bacteria $\left.\mathrm{ml}^{-1}\right)$ was deposited on a microscope slide and then left to dry. Contact angles were measured immediately after the deposition of drops of water onto the bacterial film. The reported values are the mean contact angles from three independent experiments. (b) Differential interference contrast microscopy image of a representative bacterial film showing a homogeneous and continuous covering of the slide. Bar, $30 \mu \mathrm{m}$. (c) Bacterial adherence to $n$-hexadecane. Each bacterial suspension $\left(2.4 \mathrm{ml} ; 10^{8}\right.$ bacteria $\left.\mathrm{ml}^{-1}\right)$ was mixed with $0.4 \mathrm{ml} n$ hexadecane and vortexed for $90 \mathrm{~min}$. The mixture was allowed to stand for $15 \mathrm{~min}$. The percentage of adhesion to $n$ hexadecane was calculated by using the initial $A_{405}$ of the bacterial suspension and the absorbance of the water phase after mixing as indicated in Methods. The bars represent standard deviation of five independent experiments.

Monoxenic mice. In this model, mice were challenged with either the $f b p A$ mutant or the wild-type strain. The same faecal shedding kinetics was observed for the two strains (Fig. 4). The rate of faecal shedding increased during the first hours of infection, reached a plateau after about $8 \mathrm{~h}$ and then remained constant. Even though the faecal shedding kinetics of the $f b p A$ mutant was no different from that of the wild-type strain, a significant decrease in caecal colonization was noted $\left[2.51 \times 10^{6}\right.$ c.f.u. $(\mathrm{g} \text { caeca })^{-1}$ and $7.88 \times 10^{5}$ c.f.u. $(\mathrm{g} \text { caeca) })^{-1}$ for the wild-type strain and $\mathrm{CD} \Delta \mathrm{FbpA}_{640}$ mutant, respectively; $\left.P<0.05\right]$. This reduced caecal colonization suggests a role for $\mathrm{FbpA}$ in adherence and in intestinal colonization.

Dixenic mice. We carried out a competition assay in which mice were simultaneously challenged with both the $\mathrm{CD} \Delta \mathrm{FbpA}_{640}$ mutant and the wild-type strain. The $\mathrm{CD} \Delta \mathrm{FbpA}_{640}$ mutant and $\mathrm{CD} 630 \Delta \mathrm{erm}$ showed two different kinetics (Fig. 5). In fact, the mutant shed less $C$. difficile than the wild-type strain during the first 5 days after challenge. We particularly observed a significant and important reduction of the shedding rate at $48 \mathrm{~h}, 72 \mathrm{~h}$ and $96 \mathrm{~h}$ post-challenge for the $\mathrm{CD} \Delta \mathrm{FbpA}_{640}$ mutant. After $120 \mathrm{~h}$ post-challenge, the shedding rate became similar for the two strains. Even though a lower rate of caecal colonization was observed for the $\mathrm{CD} \Delta \mathrm{FbpA}_{640}$ mutant in this model, this difference was not statistically significant. These results as well as those observed in monoxenic mice support the fact that FbpA plays a role in intestinal colonization of mice.

Human microbiota-associated mice. We also tested the capacity of the $\mathrm{CD} \Delta \mathrm{FbpA}_{640}$ mutant to colonize the gut and adhere to the caeca of human microbiota-associated mice. Wild-type and $\mathrm{CD} \Delta \mathrm{FbpA}_{640}$ mutant strains colonized at exactly the same rate (Fig. 6). The absence of difference in this model is not so surprising and could be explained by the barrier effect of the intestinal microbiota. Moreover, the colonization process is multifactorial and probably involves several adhesins. Consequently, the effect of only one adhesin is difficult to observe in such a model. 


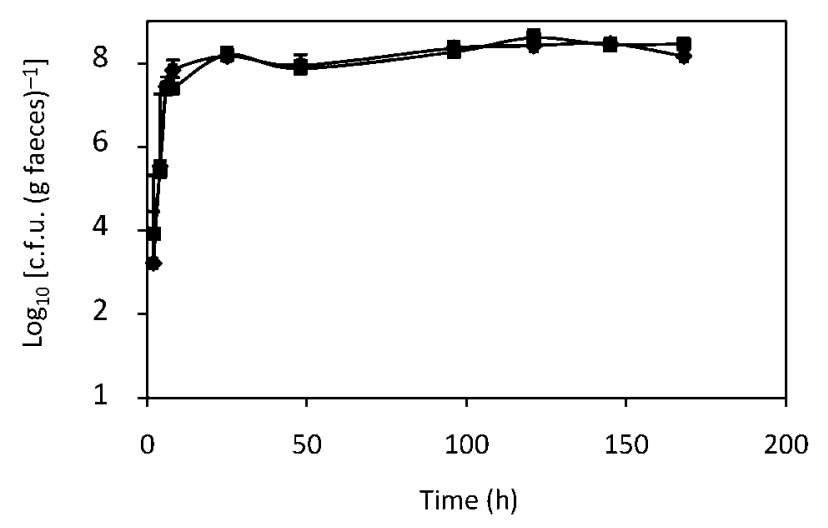

Fig. 4. Role of FbpA in intestinal colonization of monoxenic mice by C. difficile. Kinetics of intestinal implantation by wild-type strain $\mathrm{CD} 630 \Delta$ erm $(\bullet)$ and the $\mathrm{CD} \Delta \mathrm{FbpA}_{640}$ mutant $(\boldsymbol{\square})$. Mice were challenged $(n=6)$ with a total of $5 \times 10^{6}$ bacteria per mouse of each of the two strains. Faeces were collected and treated daily for a week to obtain the number of c.f.u. ( $\mathrm{g}$ faeces) ${ }^{-1}$.

C. difficile pathogenicity is mainly mediated by its two toxins, TcdA and TcdB, but other factors undoubtedly contribute to its virulence, particularly in the initial colonization process. This first step occurs before the production of toxins and involves several adhesins. Thus, it is very important to study the precise role of these adhesins in the colonization process. FbpA represents one of these adhesins. It has already been reported that $\mathrm{FbpA}$ is able to bind to soluble and to immobilized fibronectin and that it is probably implicated in cell adherence. These conclusions are based on a competitive inhibition assay using anti-Fbp antibodies and on an adherence assay of Fbp to radiolabelled Vero cells which carry fibronectin on their

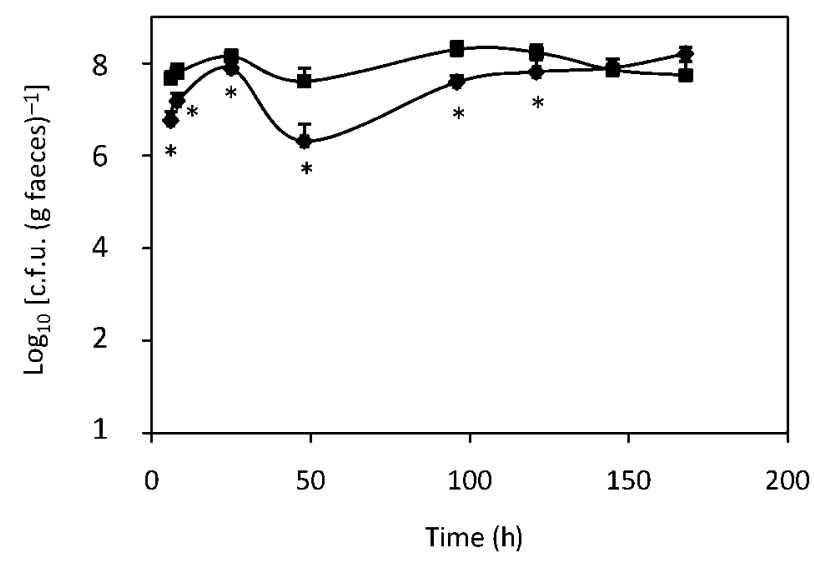

Fig. 5. Role of FbpA in intestinal colonization of dixenic mice by $C$. difficile. Kinetics of intestinal implantation by wild-type strain CD630 $\Delta$ erm ( $\boldsymbol{\square})$ and the $\mathrm{CD} \Delta \mathrm{FbpA}_{640}$ mutant $(\diamond)$. The same protocol as described for monoxenic mice was used but mice were co-infected with the two strains. Statistically significant differences $(P<0.05)$ are indicated by *.

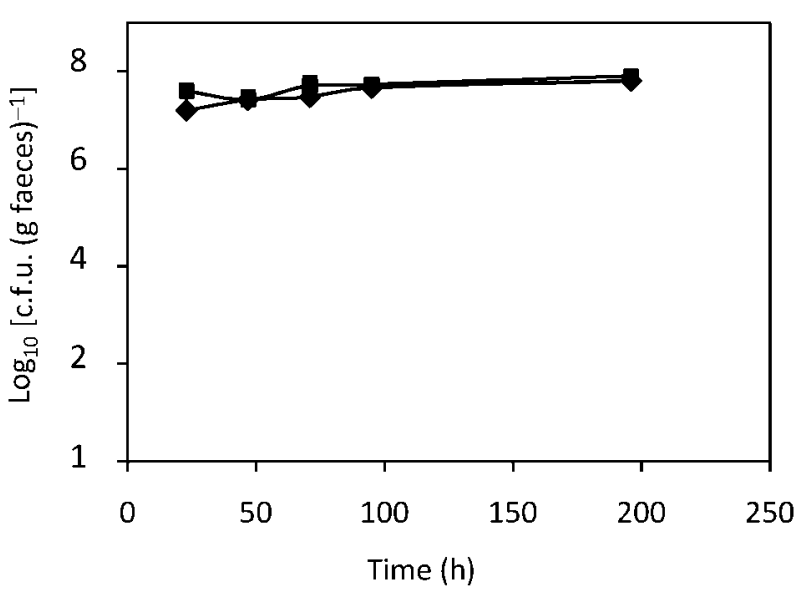

Fig. 6. Role of FbpA in colonization of human microbiota-associated mice by $C$. difficile. Kinetics of intestinal implantation by wild-type

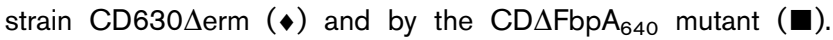
Human microbiota-associated mice $(n=6)$ were inoculated with each of the two strains and the kinetics of colonization was followed by analysing faecal shedding over time. Results are expressed as number of colonies obtained ( $\mathrm{g}$ faeces) ${ }^{-1}$.

surface (Hennequin et al., 2003). In our study, we tried to confirm the role of FbpA in cell adherence and to elucidate the role of FbpA in the initial $C$. difficile colonization process in particular. For this purpose, we constructed a $\mathrm{CD} \Delta \mathrm{FbpA}$ knockout mutant and studied the effect of this mutation in vitro on cultured epithelial cells and also in vivo using different mouse models. We demonstrated that mutation in the $f b p A$ gene affects the adherence of $C$. difficile $630 \Delta$ erm to epithelial cell lines and that adherence is increased. Both caecal colonization (in monoxenic mice) and intestinal implantation (in dixenic mice) of the $\mathrm{CD} \Delta \mathrm{FbpA}$ mutant are slower than those of the wild-type strain. Taken together, these data suggest a role for FbpA in intestinal colonization by $C$. difficile. This role is minor but not insignificant and is probably shared with other adhesins. This strengthens the idea that intestinal colonization is a complicated process which involves several colonization factors. The observed effect might also be different between strains. Thus, it could be interesting to test the effect of FbpA mutation on other strains, especially hypervirulent strains such as the NAP1/027 strain.

\section{ACKNOWLEDGEMENTS}

This work was supported by the European Collaborative Project HYPERDIFF, 'The Physiological Basis of Hypervirulence in Clostridium difficile: a Prerequisite for Effective Infection Control', grant agreement no. 223585. We would like to thank Nigel Minton and John Heap, University of Nottingham, UK, who developed the ClosTron gene knockout system, for supplying us with the pMTL007 plasmid, as well as Bruno Dupuy, Institut Pasteur, France, for supplying us with the $C$. difficile $630 \Delta$ erm strain. We also thank Catherine Ringard-Lefebvre and Véronique Rosilio, Laboratoire de Physico-Chimie des Surfaces, UMR CNRS 8612, University Paris-Sud 
11, Châtenay-Malabry, France, for their help in doing contact angle measurements, and Valérie Nicolas, IFR141 Plateforme Imagerie, University Paris-Sud 11, France, for dealing with the confocal microscopy.

\section{REFERENCES}

Bellon-Fontaine, M.-N., Rault, J. \& van Oss, C. J. (1996). Microbial adhesion to solvents: a novel method to determine the electrondonor/electron-acceptor or Lewis acid-base properties of microbial cells. Colloids Surf B Biointerfaces 7, 47-53.

Calabi, E., Calabi, F., Phillips, A. D. \& Fairweather, N. F. (2002). Binding of Clostridium difficile surface layer proteins to gastrointestinal tissues. Infect Immun 70, 5770-5778.

Cartman, S. T., Heap, J. T., Kuehne, S. A., Cockayne, A. \& Minton, N. P. (2010). The emergence of 'hypervirulence' in Clostridium difficile. Int J Med Microbiol 300, 387-395.

Cerquetti, M., Molinari, A., Sebastianelli, A., Diociaiuti, M., Petruzzelli, R., Capo, C. \& Mastrantonio, P. (2000). Characterization of surface layer proteins from different Clostridium difficile clinical isolates. Microb Pathog 28, 363-372.

Courtney, H. S., Hasty, D. L., Li, Y., Chiang, H. C., Thacker, J. L. \& Dale, J. B. (1999). Serum opacity factor is a major fibronectin-binding protein and a virulence determinant of $\mathrm{M}$ type 2 Streptococcus pyogenes. Mol Microbiol 32, 89-98.

Dramsi, S., Bourdichon, F., Cabanes, D., Lecuit, M., Fsihi, H. \& Cossart, P. (2004). FbpA, a novel multifunctional Listeria monocytogenes virulence factor. Mol Microbiol 53, 639-649.

Genth, H., Dreger, S. C., Huelsenbeck, J. \& Just, I. (2008). Clostridium difficile toxins: more than mere inhibitors of Rho proteins. Int J Biochem Cell Biol 40, 592-597.

Heap, J. T., Pennington, O. J., Cartman, S. T., Carter, G. P. \& Minton, N. P. (2007). The ClosTron: a universal gene knock-out system for the genus Clostridium. J Microbiol Methods 70, 452-464.

Hennequin, C., Porcheray, F., Waligora-Dupriet, A., Collignon, A., Barc, M., Bourlioux, P. \& Karjalainen, T. (2001). GroEL (Hsp60) of Clostridium difficile is involved in cell adherence. Microbiology 147, 87-96.

Hennequin, C., Janoir, C., Barc, M. C., Collignon, A. \& Karjalainen, T. (2003). Identification and characterization of a fibronectin-binding protein from Clostridium difficile. Microbiology 149, 2779-2787.
Holmes, A. R., McNab, R., Millsap, K. W., Rohde, M., Hammerschmidt, S., Mawdsley, J. L. \& Jenkinson, H. F. (2001). The pavA gene of Streptococcus pneumoniae encodes a fibronectinbinding protein that is essential for virulence. Mol Microbiol 41, 13951408.

Janoir, C., Péchiné, S., Grosdidier, C. \& Collignon, A. (2007). Cwp84, a surface-associated protein of Clostridium difficile, is a cysteine protease with degrading activity on extracellular matrix proteins. J Bacteriol 189, 7174-7180.

Joh, D., Wann, E. R., Kreikemeyer, B., Speziale, P. \& Höök, M. (1999). Role of fibronectin-binding MSCRAMMs in bacterial adherence and entry into mammalian cells. Matrix Biol 18, 211-223.

Lin, Y. P., Kuo, C. J., Koleci, X., McDonough, S. P. \& Chang, Y. F. (2011). Manganese binds to Clostridium difficile Fbp68 and is essential for fibronectin binding. J Biol Chem 286, 3957-3969.

Molinari, G., Talay, S. R., Valentin-Weigand, P., Rohde, M. \& Chhatwal, G. S. (1997). The fibronectin-binding protein of Streptococcus pyogenes, SfbI, is involved in the internalization of group A streptococci by epithelial cells. Infect Immun 65, 13571363.

Muñoz-Provencio, D., Pérez-Martínez, G. \& Monedero, V. (2010). Characterization of a fibronectin-binding protein from Lactobacillus casei BL23. J Appl Microbiol 108, 1050-1059.

Poxton, I. R., McCoubrey, J. \& Blair, G. (2001). The pathogenicity of Clostridium difficile. Clin Microbiol Infect 7, 421-427.

Tasteyre, A., Barc, M. C., Collignon, A., Boureau, H. \& Karjalainen, T. (2001). Role of FliC and FliD flagellar proteins of Clostridium difficile in adherence and gut colonization. Infect Immun 69, 7937-7940.

Terao, Y., Kawabata, S., Kunitomo, E., Murakami, J., Nakagawa, I. \& Hamada, S. (2001). Fba, a novel fibronectin-binding protein from Streptococcus pyogenes, promotes bacterial entry into epithelial cells, and the $f b a$ gene is positively transcribed under the Mga regulator. Mol Microbiol 42, 75-86.

Voth, D. E. \& Ballard, J. D. (2005). Clostridium difficile toxins: mechanism of action and role in disease. Clin Microbiol Rev 18, 247263.

Waligora, A. J., Hennequin, C., Mullany, P., Bourlioux, P., Collignon, A. \& Karjalainen, T. (2001). Characterization of a cell surface protein of Clostridium difficile with adhesive properties. Infect Immun 69, 21442153. 